\title{
Estimating the Demand for International Reserves Function in Nigeria: Evidence from Vector Auto- Regressions
}

\author{
Blessing Ose Oligbi $\mathrm{Ph} \mathrm{D}^{1^{*}}$, Milton A. Iyoha $\mathrm{Ph} \mathrm{D}^{2}$ \\ ${ }^{1}$ Ag Head, Department of Economics \& Development Studies, Igbinedion University, Okada, Edo State, Nigeria. \\ ${ }^{2}$ Professor of Economics, University of Benin, Benin City, Nigeria \\ *Corresponding Author
}

\begin{abstract}
This study estimates the demand for international reserves function in Nigeria using vector auto-regressions, and annual time-series data for 1980-2017. The result obtained indicates that there is a stable, long- run relationship between international reserves, exports, openness, interest rate and export earnings volatility. Variance decomposition analysis shows the main sources of economic growth variations in Nigeria are attributable to "own shocks" and only slightly to other variables, namely, exports and openness. Thus, the study recommends that the government should adopt trade and exchange rate policies to promote exports in order to increase international reserve holdings and accelerate economic growth in Nigeria.
\end{abstract}

Key words: International reserves, Nigeria, vector autoregressions

JEL classifications: F14, F30, F32, F36

\section{INTRODUCTION}

$\mathrm{E}$ ven though the world has long abandoned a fixed exchange rate system, the need for holding international reserves has remained. The need to hold reserves is even more warranted as most countries now have a "managed" exchange rate system. It should be apparent that in a world of managed exchange rates, holding of international reserve assets remains important and necessary. This is especially true for developing countries which depend heavily on the exportation of primary commodities whose prices often fluctuate widely. In any case, according to the IMF (1974), there are reasons to hold reserves apart from the financing of payments deficits. Note that the reasons which include the necessity to own reserves to facilitate foreign borrowing remained unchanged when the international monetary system of fixed exchange rates was jettisoned. International reserve assets consist of monetary gold, convertible foreign exchange, special drawing rights (SDRs), and reserve positions (gold tranche and super gold tranche) with the International Monetary Fund (IMF), owned and held by the central banks of various countries. Many researchers have found it convenient to summarize the motives for holding international reserve assets as arising from both precautionary and mercantile needs. Basically, the precautionary motive for holding international reserves refers to the need to hold foreign reserves to forestall shortage of funds that normally occur during financial crises or to serve as collateral for external debt thereby improving the country's credit worthiness or to stabilize currency volatility during the occurrence of external shocks (Aizenman \& Lee, 2005; Sula, \& Willett, 2005; Rodriguez \& Funk, 2012; Tule et al., 2015). On the other hand, the mercantile motive posits that reserve accumulation is used to facilitate exports and direct investment to the export industries (Aizenman \& Lee, 2005) or that foreign reserves serve to keep real exchange rate devalued against the dollar in order to strengthen the domestic economy (Calvo, Alejandro, \& Rudy, 2012; Shijaku, 2012).

Economists have recently started to study the determinants of the demand for international reserves by utilizing the potent technique of vector auto-regressions, which was popularized by the Nobel Laureate, Professor Christopher Sims (1986). The VAR technique has attracted enormous attention since it expedites studying the interrelations among non-stationary time-series variables, while regarding them as endogenous. Additionally, vector auto-regressions have exhibited their usefulness in time-series forecasting and for inter-temporal dynamical analysis. They have also proved their practicality in analysing impulse response functions, and for investigating forecast error variance decomposition. Accordingly, we have opted to utilize this efficacious instrument to explain the intricate nexus among international reserve assets, export receipts, export earnings volatility, openness and interest rates in Nigeria.

Accordingly, the aim of this paper is to estimate the demand for international reserves function for Nigeria using the methodology of vector auto-regressions. This paper has five sections. Section 1 deals with the Introduction while section 2 contains material on Literature Review (conceptual, theoretical and empirical). Section 3 focuses on Methodology and estimation technique while section 4 presents and interprets the econometric results of the study. Finally, section 5 contains a summary, recommendations and concluding remarks.

\section{LITERATURE REVIEW}

There have been many studies on the estimation of the demand for international reserves in both developed countries 
and for developing countries. The interest of researchers spiked with the change from fixed exchange rate system to a floating or "managed" exchange rate system in the 1970s. Note that a rising or falling reserves-to-import ratio does not necessarily follow from the change in the exchange rate system. An important contribution which threw light on this issue was the seminal paper by Heller and Khan (1978). At the theoretical level, Williamson (1973) had argued that the view of a falling reserve-import ratio depends on the critical assumption that the demand for and supply of foreign exchange do not vary with the exchange rate regime. However, this may not hold. There is also the fact that excessive capital flows may necessitate a greater use of reserves when transiting from a fixed exchange rate to a flexible exchange rate regime. Note that if there is a secular rise in excessive capital flows, usage of international reserves may actually rise with a regime shift. However, Haberler (1977) reasons that the need for a country to hold international reserves vanishes in a floating exchange rates regime since balance-of- payments surpluses and deficits are automatically remediated by changes in the exchange rate. Meantime, traditional trade theory suggests that movement toward more flexible exchange rates distinctly lowers the necessity for holding international reserves by trading countries. This controversy forms the backdrop to the Heller and Khan (1978) contribution which thoroughly studied the movements in the international reserve holdings of different groups of countries during the period of transition from a fixed exchange rate regime to a flexible exchange rate system. They investigated comprehensively whether or not the demand for reserves function remained stable during different regimes of their study, in order to confirm whether or not countries' demand for reserves remained unchanged under both regimes. The study identified a downward shift in the demand for international reserves by industrial countries (but not developing countries) consequent on the movement to a floating/managed exchange rate regime.

Earlier on, Iyoha (1976) examined the demand function for international reserves assets in the developing countries employing a distributed-lag specification. Iyoha tested his model using cross-country data from twenty-nine LDCs in 1970 and it performed well. The study expectedly used variables such as export earnings, an instability-of-exportreceipts index, the degree of openness and the return on reserves as explanatory variables. The empirical results from the study showed that, the regression equation was able to explain over $93 \%$ of the systematic variations in the reserveholding behaviour of less developed countries during the period. An important finding of that study was the significant explanatory power of the opportunity cost variable and results obtained showed that, ceteris paribus, a $10 \%$ increase in the opportunity cost of holding reserves triggers a $9 \%$ reduction in the amount of reserves held. In the study, Iyoha was able to distinguish between actual and desired levels of reserves contrary to the study of Kenen and Yudin (1965) that assumed actual and desired levels of reserves are the same. According to Iyoha (1976), actual levels of international reserves may in fact diverge from desired levels because of lags in adjustment arising from institutional inertia and rigidity, the economic costs of adjustment, and the presence of uncertainty. Actual reserves are the observed amounts held; optimum reserves refer to the amount a country should hold, using a welldefined criterion such as the maximization of the discounted sum of national income over a given horizon. The study adopted a partial adjustment model which hypothesized that in any period, the actual reserve level is adjusted toward its optimum level by some proportion of the discrepancy between optimum and actual. The main determinants of demand for international reserves were found to include exports, the volatility of export earnings, the return on reserves and openness. Regarding openness, Iyoha's result corroborated the earlier finding by Cooper (1968) that the more "open" an economy is, the higher the optimal level of reserves will be since the more open an economy, the greater its susceptibility to external perturbation. A country which is more susceptible to external disequilibrium should keep a higher level of precautionary balances in the optimal portfolio. The higher the interest rate on foreign exchange holdings, the higher will be the optimal reserve level since a higher interest rate implies a lower opportunity cost of holding reserves. The higher the variability of export earnings is, that is, the greater the instability of export receipts, the higher will be the optimum level of reserve holdings, Iyoha (1973).

Over the decades, other authors have established different findings in relation to the demand of international reserves, These include Shaibu \& Izedonmi (2020), who examined Nigeria's external reserves dynamics with an auto-regressive distributed-lag modelling approach that explains the short-run and long-run impacts of selected macroeconomic variables, viz., exchange rate, inflation, interest rate, crude oil price, and real gross domestic product on foreign reserves in Nigeria from 1986 to 2018. Interestingly, they found that, in the long run, only the previous value of foreign reserves was significant in explaining foreign reserve holdings in Nigeria.

Other recent studies on Nigeria include: Oyeniran and Alamu (2020); Ojiako (2020); Samuel, Omotayo \& Olusegun (2019); Kalu, Ugwu, Ndubuaka \& Ifeanyi (2019); Chinedu \& Edet (2019); Nwafor (2017); Akomobi \& Ugwunna (2017); and Akinwumi \& Adekoya (2016).

The Oyeniran and Alamu study utilized the "buffer stock model" to estimate the optimal level of international reserves in Nigeria. Using the ARDL methodology, they found that the main determinants of optimal reserves are the adjustment cost of holding international reserves and exchange rate volatility. Their results suggest that Nigeria's international reserve holding behaviour is more sensitive to the precautionary motive than the mercantilist motive for reserve holding.

Ojiako, I. A. (2020), investigated the link between external reserves and economic performance in Nigeria from 1981 through 2018 utilizing Bounds test and ARDL approaches. 
Empirical evidence obtained established a long-run relationship between stock total foreign reserves and economic performance during the period studied. The result was interpreted as supporting the view that a booming economy tends to attract foreign direct investment and hence boost the stock of foreign reserves.

Samuel, A.O., Omotayo, E., \& Olusegun, E.A. (2019) examined the relationship between Nigeria's external reserve and trade between 1987 and 2017. They utilized the ARDL Bound test methodology to test for both long run and short run relationship. In addition, they used Granger Causality to test for the causal relations. Examination of the regression results showed that exchange rate, oil exports and non-oil exports had positive impact on external reserves while oil import and non-oil import had negative effects on external reserve. The Granger Causality test revealed that exchange rate, non-oil export, oil export and oil import has unidirectional causal relationship with the causality running from each variable to external reserves. However, the authors found that there is bi-directional causal relationship between non-oil imports and external reserves. The study recommends that more attention should be given to the development of the nonoil export sector which was found to be relatively stable. In this way, the country would be in a position to own a large and growing stock of external reserves.

Kalu, E.B, Ugwu, O.E, Ndubuaku, V.C, \& Ifeanyi, O.P, (2019) set out to measure the responsiveness of foreign exchange reserves to exchange rate variables in Nigeria, using an ARDL model during the years 1996through 2016. The empirical results showed that there exists a positive and significant relation between the real exchange rate and foreign exchange reserves. However, they found that the nominal exchange rate has a positive but non-significant relationship with foreign exchange reserves during the period of study. The authors concluded by drawing some relevant lessons for policy makers keen on optimal management of the country's foreign exchange reserves.

Chinedu, N.G., \& Edet, A.S. (2019) undertook an investigation of the macroeconomic implications of external reserves management in Nigeria utilizing an Ex-Post Facto research design and an ARDL regression model during the period 1986 through 2016. The study sought to examine the impact on external reserves of the exchange rate, trade openness, inflation rate, external debt, economic growth rate and real interest rate. The empirical evidence showed that the exchange rate has a significant and positive impact on external reserves; trade openness was found to have a negative but insignificant effect on external reserves. The authors found that inflation rate has a significant negative effect on external reserves and external debt also showed a significant negative impact on foreign exchange reserves. Finally, it was found that rate of growth rate and real interest rate had a positive but insignificant impact on external reserves. In sum, price volatility, exchange rate volatility and external debt overhang are significant determinants of the aggregate stock of Nigeria's external reserves.

Nwafor (2017) presented research work titled External Reserves: Panacea for Economic Growth in Nigeria, with data covering the years from 2004 through 2015, and using the Ordinary Least Squares (OLS) regression technique. The study found that external reserves had no positive significant impact on economic growth in Nigeria within the period studied and that external reserves have no significantly positive significant effect on exchange rate in Nigeria. Other findings obtained from data analysis revealed that Nigeria's foreign exchange reserves declined marginally within the period under study and that it was attributable to the 20072008 global financial crisis and the nonchalant attitude of the government towards accumulation of international reserves. It was recommended, inter alia, that in addition to accumulating ample foreign exchange reserves, the country should emphasize proper management of reserves.

Akamobi \&Ugwunna (2017, analyzed the determinants of foreign reserves in Nigeria during the period from 1970 through 2013, utilizing the Ordinary Least Squares regression technique for the analysis. Results obtained showed that oil price and domestic credit are the main determinants of foreign reserve holdings. Other variables such as domestic income, price level, interest rate and exchange rate can also be considered as determinants of foreign reserve but only in the long run. The Granger Causality test indicates a unidirectional relationship between oil price and foreign exchange reserves. The study recommends that the Nigerian government should encourage other sources of foreign reserve apart from oil as a way of minimizing the effect of oil price volatility on the stock of foreign exchange reserves and on the economy itself.

Akinwunmi \& Adekoya (2016) carried out a study that examined external reserves management and its effects on Nigerian economic growth during the years 1985 through 2013. They employed multiple regression technique to test for the relationship between the explanatory variables and external reserves management. The empirical results showed that the explanatory variables accounted for over $90 \%$ of the systematic variations in the stock of external reserves during the period. In addition, the multiple regression results showed that GDP, MPR and FDI are highly statistically significant while IFR and EXR are statistically insignificant. The authors therefore concluded that FDI, MPR and GDP are key determinants of external reserves holdings in Nigeria..

Osigwe, Okechukwu, and Onoja (2015) investigated the determinants of foreign reserves in Nigeria employing cointegration and error correction modelling. Results of the estimated short-run coefficients indicated that real gross domestic product and oil exports are positive and significant determinants of foreign reserves. The study found exchange rate was a significant but negative determinant of foreign reserve holdings. Also, foreign direct investment (FDI) inflows were found to be a positive and significant 
determinant of foreign reserves only in its first period lag while lending rate was discovered to be a negative and insignificant determinant. However, the coefficient of inflation rate was negative but a rather significant determinant of foreign reserve holdings.

Bankole et al (2011), examined the demand for international reserves in Nigeria, using a dynamic modelling methodology. They found that a high level of international reserves is needed to support effective macroeconomic policy making and boost the country's credit status. The findings from the study revealed that current account volatility and previous reserve levels are the main drivers of the country's reserve holding in the short term. However, for the longer term, lagged and current values of money supply were found to be key determinants of international reserves. Thus, the study concludes that export expansion is critical for successful international reserves management.

In an influential study on the "Formulation and Implementation of Strategies for Effective Management of External Reserves", Ekpo and Omoruyi (2011) discussed, inter alia, the rationale for holding international reserves. According to them, the motives include: (i) safeguarding the value of the domestic currency; (ii) effecting timely settlement of international payments obligations; (iii) accumulating wealth; (iv) facilitating intervention in the foreign exchange market by the monetary authority; (v) boosting a country's credit worthiness; and (vi) providing a buffer against external shocks.

Usman and Ibrahim (2010) using an error correction model specified a simple long run external reserves demand equation from 1986-2006. Their study showed that demand for external reserves in Nigeria is driven mainly by current account variability, real exchange rate and opportunity cost of holding reserves. The empirical results show that current account variability and real exchange rate variables have positive and statistically significant coefficients. The opportunity cost of holding reserves has a negative coefficient while GDP was found to be insignificant.

It should be noted that numerous past studies using varying methodologies have found many variables capable of explaining the demand for international reserves for both advanced and developing countries. In addition to variables discussed above, they include metrics of "reserve adequacy" such as months of import cover (measured by the reserveimport ratio, $\mathrm{R} / \mathrm{M}$ ); international reserves as a ratio of broad money supply (R/M2); and for developing countries, the ratio of international reserves to total short-term external debt (R/TSTED), originally proposed by Greenspan and Guidetti and often referred to as the Greenspan-Guidetti rule. Some analysts however suggest that in an environment of high volatility of capital flows which inevitably tend to expose the vulnerability of LDCs to capital account crises, the Greenspan-Guidetti rule should be used in combination with the reserve-import ratio to gauge a developing country's reserve adequacy.

\section{DATA AND METHODOLOGY}

\subsection{Data}

This study utilizes annual time-series data which covers a period of 37 years, between 1981 and 2017. Data used were sourced from the Statistical Bulletin of the Central Bank of Nigeria (CBN). In order to fully capture the hypothesized relationships between international reserves, exports receipts, export earnings volatility, openness and opportunity cost of reserve holding (proxied by the rate of interest), utilization of the VAR technique is indicated.

\subsection{Methodology}

This paper makes use of the methodology of vector autoregressions (VARs). Basically, the methodology encompasses the use of multivariate co-integration analysis, unit roots testing, pair-wise Granger Causality testing, forecast error variance decomposition (FEVD) and impulse response functions (IRFs) which are utilized to examine interrelations among variables in the vector auto-regression system. Therefore, basically, we attempt to analyse the dynamic relationships between international reserves, exports, export earnings volatility (measured by GARCH), openness (measured by the import-income ratio) and interest rate. The vector auto-regression methodology sidesteps the endogenous variable - exogenous variable conundrum since it considers all variables as endogenous. It is a dynamical system of equations in which the current value of each variable in the system is taken to depend on the past values of that variable and on the values of all other variables in the system. Finally, we employ the Akaike Information Criteria (AIC) to select the optimal lag length for the determinants of international reserve holdings.

The VAR model for this study posits that international reserve assets, total exports, export earnings volatility and interest rate (a proxy for the opportunity cost of holding reserves) are simultaneously interrelated. This model derives from earlier studies by Tule et al (2015), Aizenmam and Lee (2005), Heller and Khan (1978), and Iyoha (1976) though with some modifications in model building, variable selections and methodology. The VAR model for our study is stipulated thus;

$$
V_{t}=\alpha+\sum_{i=1}^{k} A_{i} V_{t-1}+U_{t} \ldots \ldots \ldots \ldots \ldots \ldots \ldots
$$

$\mathrm{V}_{\mathrm{t}}=(\mathrm{RES}, \mathrm{XPORT}, \mathrm{VOL}, \mathrm{OPN}$, INTR $)$

$\mathrm{V}_{\mathrm{t}}=$ the vector of international reserve assets, total export, export earnings volatility, openness and interest rate. 
$\mathrm{A}_{\mathrm{i}}=$ matrix of coefficients of all variables.

$\mathrm{V}_{\mathrm{t}-1}=$ vector of lagged variables.

\section{RESULTS PRESENTATION AND DISCUSSIONS}

$\mathrm{U}_{\mathrm{t}}=$ vector of error terms.

\subsection{Summary of Results of the Descriptive Statistic}

Table 1: Descriptive Statistics

\begin{tabular}{|c|c|c|c|c|c|}
\hline & RES & XPORT & VOL & OPN & INTR \\
\hline Mean & 196799 & 4429.269 & 1673496 & 51.42736 & 7.439043 \\
\hline Median & 91701.66 & 1309.543 & 238149.1 & 55.84639 & 5.33 \\
\hline Maximum & 701674.6 & 15262.01 & 22765120 & 81.81285 & 18.8 \\
\hline Minimum & 5479.7 & 7.5025 & -1461822 & 21.44693 & 1.410541 \\
\hline Std. Dev. & 203032.2 & 5367.485 & 4214617 & 16.16925 & 5.089927 \\
\hline Skewness & 0.883982 & 0.883834 & 3.894403 & -0.28685 & 0.76397 \\
\hline Kurtosis & 2.361922 & 2.270981 & 18.91267 & 2.185402 & 2.20574 \\
\hline Jarque-Bera & 5.446467 & 5.636517 & 483.896 & 1.530415 & 4.57174 \\
\hline Probability & 0.065662 & 0.05971 & 0 & 0.465237 & 0.101686 \\
\hline Sum & 7281561 & 163882.9 & 61919370 & 1902.812 & 275.2446 \\
\hline Sum Sq. Dev. & $1.48 \mathrm{E}+12$ & $1.04 \mathrm{E}+09$ & $6.39 \mathrm{E}+14$ & 9412.002 & 932.6647 \\
\hline Observations & 37 & 37 & 37 & 37 & 37 \\
\hline
\end{tabular}

Source: Authors' computation using E-views 9.0.

The summary descriptive statistics for all the variables are reported in Table 1 . The results in Table 1 show that the average and median values for all the variables employed for this study are in conformity with the usual annual time series data behavior. Normality test uses the null hypothesis of normality against the alternative hypothesis of non-normality.
If the probability value is less than the Jacque Bera chi-square at the 5\% level of significance, the null hypothesis of the regression is not rejected. All the variables are normally distributed since all the probabilities are less than the Jarque Bera chi-square distribution.

Table 2: CORRELATION MATRIX

\begin{tabular}{|c|c|c|c|c|c|}
\hline & RES & XPORT & VOL & OPN & INTR \\
\hline RES & 1 & 0.8977632 & 0.4243367 & 0.0348977 & -0.672103 \\
\hline XPORT & 0.8977632 & 1 & 0.5043087 & -0.0769 & -0.705575 \\
\hline VOL & 0.4243367 & 0.5043087 & 1 & -0.159981 & -0.281465 \\
\hline OPN & 0.0348977 & -0.0769 & -0.159981 & 1 & -0.06016 \\
\hline INTR & -0.672103 & -0.705575 & -0.281465 & -0.06016 & 1 \\
\hline
\end{tabular}

Source: Authors' computation using E-views 9.0.

The empirical evidence in Table 2 establishes the degree, extent and direction of relationships among the variables. It can be seen that, in general, the correlation among the variables are high between international reserves and exports, and between international reserves and interest rate; moderate between international reserves and export earnings volatility; and low between international reserves and openness.

\subsection{Testing for Unit Root}

Table 3: Unit Root Test Results

\begin{tabular}{|c|c|c|c|c|c|c|c|}
\hline \multicolumn{8}{|c|}{ ADF Test } \\
\hline \multirow[b]{2}{*}{ Variables } & \multicolumn{3}{|c|}{ Levels } & \multicolumn{3}{|c|}{$1^{\text {st }}$ Difference } & \multirow[b]{2}{*}{$\mathbf{I}(\mathbf{d})$} \\
\hline & ADF Stat & $\begin{array}{c}\text { Critical } \\
\text { Value }(5 \%)\end{array}$ & Inference & ADF Stat & $\begin{array}{c}\text { Critical } \\
\text { Value } \\
(5 \%) \\
\end{array}$ & Inference & \\
\hline RES & -1.408 & -2.948 & NS & -4.13 & -2.94 & $\mathrm{~S}$ & $\mathrm{I}(1)$ \\
\hline XPORT & 1.735 & -2.957 & NS & -4.66 & -2.95 & S & $\mathrm{I}(1)$ \\
\hline VOL & -6.211 & -2.945 & S & -10.8 & -2.95 & $\mathrm{~S}$ & $\mathrm{I}(1)$ \\
\hline OPN & -2.63 & -2.945 & NS & -8.12 & -3.54 & $\mathrm{~S}$ & $\mathrm{I}(1)$ \\
\hline INTR & -1.013 & -2.945 & NS & -6.09 & -3.58 & $\mathrm{~S}$ & $\mathrm{I}(1)$ \\
\hline
\end{tabular}


Source: Authors' computation using E-views 9.0.

Note: "NS" stands for non-stationary while "S" stands for stationary; "d" is the order of integration.

Testing for the stationarity of variables cannot be downplayed when analyzing macroeconomic time-series data. The reason for this is because specifying a relationship between nonstationary variables (which are not co-integrated) would lead to "spurious" or "nonsense" results. Thus, it is necessary to confirm that the variables do not have "unit roots" but if they do, they must be co-integrated in order for us to proceed. Results of the unit root test presented in Table 3 reveal that all the variables used in this study are stationary at levels or in first differences. We can therefore proceed to test for cointegration.

\subsection{Testing for Co-integration}

In this study, we test for co-integration not by using the ADF test suggested by Engle and Granger (1987) but by utilizing the Johansen estimation technique whose optimality has been shown by Phillips (1991) in terms of symmetry, unbiased-ness and efficiency properties. A Monte Carlo study by Gonzalo (1994) demonstrated the superior properties of the Johansen technique relative to several other co-integration techniques. To implement Johansen's procedure, we need to determine the optimal lag in the VAR model. Our approach for choosing the lag length was to test up from a general $\operatorname{VAR}(1)$ system until increasing the order of the $V A R$ by one lag could not be rejected using a likelihood ratio test statistic.

Table 4: JOHANSEN COINTEGRATION TEST RESULTS

Unrestricted Cointegration Rank Test (Trace)

\begin{tabular}{ccccc}
\hline \hline $\begin{array}{c}\text { Hypothesized } \\
\text { No. of CE(s) }\end{array}$ & Eigenvalue & $\begin{array}{c}\text { Trace } \\
\text { Statistic }\end{array}$ & $\begin{array}{c}0.05 \\
\text { Critical Value }\end{array}$ & Prob. $^{* *}$ \\
\hline \hline & & & & \\
None * & 0.810945 & 97.31590 & 69.81889 & 0.0001 \\
At most 1 & 0.506364 & 40.68151 & 47.85613 & 0.1990 \\
At most 2 & 0.279939 & 16.67897 & 29.79707 & 0.6636 \\
At most 3 & 0.148857 & 5.512693 & 15.49471 & 0.7522 \\
At most 4 & 0.000963 & 0.032755 & 3.841466 & 0.8563 \\
& & & & \\
\hline \hline
\end{tabular}

Unrestricted Cointegration Rank Test (Maximum Eigenvalue)

\begin{tabular}{ccccc}
\hline \hline $\begin{array}{c}\text { Hypothesized } \\
\text { No. of CE(s) }\end{array}$ & Eigenvalue & $\begin{array}{c}\text { Max-Eigen } \\
\text { Statistic }\end{array}$ & $\begin{array}{c}0.05 \\
\text { Critical Value }\end{array}$ & Prob. $^{* *}$ \\
\hline \hline & & & & \\
None * & 0.810945 & 56.63439 & 33.87687 & 0.0000 \\
At most 1 & 0.506364 & 24.00254 & 27.58434 & 0.1346 \\
At most 2 & 0.279939 & 11.16628 & 21.13162 & 0.6307 \\
At most 3 & 0.148857 & 5.479938 & 14.26460 & 0.6804 \\
At most 4 & 0.000963 & 0.032755 & 3.841466 & 0.8563 \\
\hline \hline
\end{tabular}

Source: Authors' computation using E-views 9.0.

The Johansen tests for co-integration entails both trace and maximum eigen values of unrestricted co-integration ranks. This leads to a rejection of the hypotheses of no co-integrating equations. It can be verified that the absolute values of the trace and maximum eigen statistics are greater than their respective critical values at 5 percent significance level. (See table above). This implies that the demand for international reserves, exports, interest rate, openness and export earnings volatility are co-integrated. This finding confirms the existence of a long-run relationship among the aforementioned variables. Thus, any short-term difference in their respective values will disappear in the longer term. 
Table 5: VECTOR AUTOREGRESSION ESTIMATES

Sample (adjusted): 19832017

Standard errors in ( ) \& t-statistics in [ ]

\begin{tabular}{|c|c|c|c|c|c|}
\hline & RES & XPORT & INTR & OPN & VOL \\
\hline $\operatorname{RES}(-1)$ & $\begin{array}{r}0.985372 \\
(0.18315) \\
{[5.38013]}\end{array}$ & $\begin{array}{r}-0.009871 \\
(0.00375) \\
{[-2.63422]}\end{array}$ & $\begin{array}{r}3.40 \mathrm{E}-06 \\
(5.7 \mathrm{E}-06) \\
{[0.59762]}\end{array}$ & $\begin{array}{r}1.55 \mathrm{E}-05 \\
(3.9 \mathrm{E}-05) \\
{[0.39440]}\end{array}$ & $\begin{array}{r}-16.69568 \\
(8.31236) \\
{[-2.00854]}\end{array}$ \\
\hline RES(-2) & $\begin{array}{r}-0.412516 \\
(0.17770) \\
{[-2.32139]}\end{array}$ & $\begin{array}{c}0.011731 \\
(0.00364) \\
{[3.22633]}\end{array}$ & $\begin{array}{r}-7.23 E-07 \\
(5.5 E-06) \\
{[-0.13114]}\end{array}$ & $\begin{array}{r}-7.97 \mathrm{E}-06 \\
(3.8 \mathrm{E}-05) \\
{[-0.20895]}\end{array}$ & $\begin{array}{r}-0.457137 \\
(8.06509) \\
{[-0.05668]}\end{array}$ \\
\hline XPORT(-1) & $\begin{array}{r}23.76748 \\
(9.89819) \\
{[2.40120]}\end{array}$ & $\begin{array}{c}1.363377 \\
(0.20252) \\
{[6.73192]}\end{array}$ & $\begin{array}{r}-0.000231 \\
(0.00031) \\
{[-0.75370]}\end{array}$ & $\begin{array}{c}0.000116 \\
(0.00213) \\
{[0.05465]}\end{array}$ & $\begin{array}{r}639.7704 \\
(449.234) \\
{[1.42414]}\end{array}$ \\
\hline XPORT(-2) & $\begin{array}{r}-6.123180 \\
(9.22848) \\
{[-0.66351]}\end{array}$ & $\begin{array}{r}-0.357893 \\
(0.18882) \\
{[-1.89540]}\end{array}$ & $\begin{array}{r}-2.71 \mathrm{E}-05 \\
(0.00029) \\
{[-0.09453]}\end{array}$ & $\begin{array}{r}-3.00 \mathrm{E}-05 \\
(0.00198) \\
{[-0.01515]}\end{array}$ & $\begin{array}{r}1163.728 \\
(418.839) \\
{[2.77846]}\end{array}$ \\
\hline INTR(-1) & $\begin{array}{r}4453.163 \\
(6206.78) \\
{[0.71747]}\end{array}$ & $\begin{array}{r}-9.598015 \\
(126.995) \\
{[-0.07558]}\end{array}$ & $\begin{array}{c}0.719767 \\
(0.19252) \\
{[3.73859]}\end{array}$ & $\begin{array}{r}-1.103132 \\
(1.33260) \\
{[-0.82780]}\end{array}$ & $\begin{array}{r}263050.5 \\
(281698 .) \\
{[0.93380]}\end{array}$ \\
\hline INTR(-2) & $\begin{array}{r}-6204.075 \\
(6072.17) \\
{[-1.02172]}\end{array}$ & $\begin{array}{r}-48.67210 \\
(124.241) \\
{[-0.39176]}\end{array}$ & $\begin{array}{r}0.109119 \\
(0.18835) \\
{[0.57935]}\end{array}$ & $\begin{array}{r}1.608447 \\
(1.30370) \\
{[1.23375]}\end{array}$ & $\begin{array}{r}25895.37 \\
(275589 .) \\
{[0.09396]}\end{array}$ \\
\hline OPN(-1) & $\begin{array}{r}941.7483 \\
(923.559) \\
{[1.01969]}\end{array}$ & $\begin{array}{r}22.01048 \\
(18.8967) \\
{[1.16478]}\end{array}$ & $\begin{array}{r}-0.005846 \\
(0.02865) \\
{[-0.20407]}\end{array}$ & $\begin{array}{r}0.464782 \\
(0.19829) \\
{[2.34396]}\end{array}$ & $\begin{array}{r}24462.03 \\
(41916.2) \\
{[0.58359]}\end{array}$ \\
\hline OPN(-2) & $\begin{array}{r}-358.4163 \\
(892.878) \\
{[-0.40142]}\end{array}$ & $\begin{array}{r}-9.932142 \\
(18.2689) \\
{[-0.54366]}\end{array}$ & $\begin{array}{r}-0.057786 \\
(0.02770) \\
{[-2.08646]}\end{array}$ & $\begin{array}{c}0.152667 \\
(0.19170) \\
{[0.79638]}\end{array}$ & $\begin{array}{r}31575.05 \\
(40523.7) \\
{[0.77917]}\end{array}$ \\
\hline $\operatorname{VOL}(-1)$ & $\begin{array}{r}-0.006795 \\
(0.00333) \\
{[-2.03912]}\end{array}$ & $\begin{array}{r}-5.87 \mathrm{E}-05 \\
(6.8 \mathrm{E}-05) \\
{[-0.86162]}\end{array}$ & $\begin{array}{r}7.65 \mathrm{E}-08 \\
(1.0 \mathrm{E}-07) \\
{[0.73980]}\end{array}$ & $\begin{array}{r}-2.10 \mathrm{E}-07 \\
(7.2 \mathrm{E}-07) \\
{[-0.29307]}\end{array}$ & $\begin{array}{r}-0.696589 \\
(0.15124) \\
{[-4.60580]}\end{array}$ \\
\hline VOL(-2) & $\begin{array}{r}-0.004947 \\
(0.00335) \\
{[-1.47570]}\end{array}$ & $\begin{array}{r}-0.000260 \\
(6.9 E-05) \\
{[-3.78402]}\end{array}$ & $\begin{array}{r}3.59 \mathrm{E}-08 \\
(1.0 \mathrm{E}-07) \\
{[0.34486]}\end{array}$ & $\begin{array}{r}-8.42 \mathrm{E}-07 \\
(7.2 \mathrm{E}-07) \\
{[-1.16964]}\end{array}$ & $\begin{array}{r}-0.713813 \\
(0.15215) \\
{[-4.69154]}\end{array}$ \\
\hline C & $\begin{array}{r}16314.01 \\
(59817.5) \\
{[0.27273]}\end{array}$ & $\begin{array}{c}320.3512 \\
(1223.91) \\
{[0.26174]}\end{array}$ & $\begin{array}{r}4.840031 \\
(1.85544) \\
{[2.60857]}\end{array}$ & $\begin{array}{r}16.01349 \\
(12.8429) \\
{[1.24688]}\end{array}$ & $\begin{array}{c}-5129030 . \\
(2714849) \\
{[-1.88925]}\end{array}$ \\
\hline R-squared & 0.935884 & 0.961533 & 0.905389 & 0.541867 & 0.701303 \\
\hline Adj. R-squared & 0.909170 & 0.945505 & 0.865967 & 0.350978 & 0.576847 \\
\hline Sum sq. resids & $9.15 E+10$ & 38307483 & 88.03920 & 4218.030 & $1.88 \mathrm{E}+14$ \\
\hline S.E. equation & 61746.88 & 1263.386 & 1.915281 & 13.25712 & 2802413. \\
\hline F-statistic & $\begin{array}{r}35.03238 \\
-4291382\end{array}$ & $\begin{array}{r}59.99140 \\
-293.0145\end{array}$ & $\begin{array}{r}22.96695 \\
-65.80545\end{array}$ & $\begin{array}{r}2.838650 \\
-1335189\end{array}$ & $\begin{array}{r}5.634909 \\
-5626699\end{array}$ \\
\hline
\end{tabular}




\begin{tabular}{|c|c|c|c|c|c|}
\hline Akaike AIC & 25.15075 & 17.37226 & 4.388883 & 8.258224 & 32.78114 \\
\hline Schwarz SC & 25.63958 & 17.86108 & 4.877706 & 8.747048 & 33.26996 \\
\hline Mean dependent & 206086.9 & 4681.820 & 7.478417 & 51.90773 & 1786802. \\
\hline S.D. dependent & 204879.8 & 5412.016 & 5.231510 & 16.45582 & 4308073. \\
\hline \multicolumn{2}{|c|}{ Determinant resid covariance (dof adj.) } & $1.10 \mathrm{E}+31$ & & & \\
\hline \multicolumn{2}{|c|}{ Determinant resid covariance } & $1.66 \mathrm{E}+30$ & & & \\
\hline \multicolumn{2}{|l|}{ Log likelihood } & -1466.089 & & & \\
\hline \multicolumn{2}{|c|}{ Akaike information criterion } & 86.91938 & & & \\
\hline \multicolumn{2}{|l|}{ Schwarz criterion } & 89.36350 & & & \\
\hline \multicolumn{2}{|c|}{ Number of coefficients } & 55 & & & \\
\hline
\end{tabular}

Source: Authors' computation using E-views 9.0.

The vector auto-regression estimates enable us to examine the behavioral and technical disposition of the various variables in their respective period lags - in this case, 1 to 2 period lags using the Ordinary Least Square techniques to examine each of the equations in their unrestricted VAR nature, and drawing out various diagnostic statistics for policy analysis. (See Table 5).

The results of the estimates of a single equation in the unrestricted VAR with international reserves as the dependent variable revealed that the one-period lagged value of the dependent variable and the one-period lagged value of exports were individually significant at 5 percent significance level, while those of export earnings volatility, openness, and interest rate were statistically insignificant.

The results of the estimates of a single equation in the unrestricted VAR with exports as the dependent variable revealed that the one-period lagged value of the dependent variable and the two period lagged value of international reserves were statistically significantly different from zero at the 5 percent level. However, the coefficients of export earnings volatility, openness, and the rate of interest were statistically insignificant.

The results of the estimates of a single equation in the unrestricted VAR with the rate of interest as the dependent variable showed that the one-period value of the dependent variable was statistically significant at 5 per cent level. However, the coefficients of international reserves, exports, openness and export earnings volatility were not found to be significant at any lag.

The results of the estimates of a single equation in the unrestricted VAR with openness as the dependent variable revealed that only the one-period lagged value of the dependent variable was statistically significant at 5 percent. The coefficients of all the other variables (international reserves, exports, and interest rate) were found to be insignificant at the 5 per cent level for all lags.

The results of the estimates of a single equation in the unrestricted VAR with export earnings volatility as the dependent variable revealed that the one-period lagged value of volatility and the two-period lagged value of exports are the only variables which are significantly different from zero at the 5 percent level. The coefficients of all the other variables are insignificant at the 5 percent level and for all lags.

\section{Forecast Error Variance Decomposition Test}

Estimates of FEVDs for all variables during a 10-year horizon are given in Table 6 . FEVDs of the respective variables enable us to appraise the short-run dynamical attributes of variables, showing FEVD share for a given variable which is attributable to own innovations or shock, and to innovations or shocks in other variables.

Table 6: FORECAST ERROR VARIANCE DECOMPOSITION ESTIMATES

\begin{tabular}{|c|c|c|c|c|c|c|}
\hline Variables & Quarters & RES & XPORT & INTR & OPN & VOL \\
\hline \multirow{4}{*}{ FEVD of RES } & 1 & $\mid 100.00$ & 0.00 & 0.00 & 0.00 & 0.00 \\
\cline { 2 - 7 } & 5 & $\mid 67.59$ & 13.73 & 6.46 & 7.55 & 4.64 \\
\cline { 2 - 7 } & 10 & $\mid 58.12$ & 8.88 & 15.75 & 13.03 & 4.20 \\
\hline \multirow{3}{*}{$\begin{array}{c}\text { FEVD of } \\
\text { XPORT }\end{array}$} & 1 & $\mid 45.26$ & 54.73 & 0.00 & 0.00 & 0.00 \\
\cline { 2 - 7 } & 5 & $\mid 38.13$ & 41.16 & 8.50 & 7.17 & 4.96 \\
\hline \multirow{3}{*}{$\begin{array}{c}\text { FEVD of } \\
\text { INTR }\end{array}$} & 10 & $\mid 48.93$ & 17.50 & 15.43 & 13.23 & 4.89 \\
\cline { 2 - 7 } & 1 & $\mid 0.58$ & 0.07 & 99.33 & 0.00 & 0.00 \\
\cline { 2 - 7 } & 10 & $\mid 1.94$ & 1.27 & 73.88 & 21.88 & 1.01 \\
\hline
\end{tabular}




\begin{tabular}{|c|c|c|c|c|c|c|}
\hline \multirow{3}{*}{ FEVD of OPN } & 1 & $\mid 2.86$ & 0.32 & 3.33 & 93.50 & 0.00 \\
\cline { 2 - 7 } & 5 & $\mid 6.82$ & 0.40 & 6.03 & 84.84 & 1.89 \\
\cline { 2 - 7 } & $\underline{10}$ & $\underline{17.63}$ & $\underline{1.04}$ & $\underline{6.87}$ & $\underline{81.86}$ & $\underline{2.58}$ \\
\hline FEVD of & 1 & $\mid 0.25$ & 2.20 & 6.74 & 20.93 & 70.08 \\
\hline VOL & $\underline{5}$ & $\underline{12.37}$ & $\underline{8.18}$ & $\underline{4.05}$ & $\underline{24.47}$ & $\underline{60.90}$ \\
\hline & $\underline{10}$ & $\underline{15.88}$ & $\underline{7.88}$ & $\underline{4.46}$ & $\underline{21.03}$ & $\underline{50.73}$ \\
\hline
\end{tabular}

Source: Authors' computation using E-views 9.0.

The FEVD for RES the Table above shows that the amount of variation experienced in RES is largely accounted for by its "own shock" to as high as $100 \%$ in the first period and falls to about $58.12 \%$ at horizon's end. However, the shocks in XPORT, INTR, OPN and VOL range between $0 \%$ to $8.8 \%$, $0 \%$ to $15.75 \%, 0 \%$ to $13.03 \%$ and $0 \%$ to $4.2 \%$ respectively. Thus, the results reveal that variations in international reserves are predominantly explained by "own shock" and moderately by the variations in INTR and OPN, and only slightly by the variability of the shocks associated with XPORT and VOL.

The forecast error of variance in XPORT is largely dependent on its "own innovations" which account for about 55\% at the beginning of the period and decline to about $17.5 \%$ at the end of the time horizon. Similarly, the variations in the shocks of RES, INTR, OPN and VOL range between $45.26 \%$ - 48.93\%, $0 \%-15.43 \%, 0 \%-13.23 \%$ and $0 \%-4.89 \%$ respectively during the horizon. Thus, the substantial variation in exports results from its own shocks, and moderately from variations in the shocks of the other variables.

FEVD in INTR is predominantly attributed to the variation in its "own shock" of about $99.33 \%$ at the beginning of the period but plummets to $49.55 \%$ at horizon's end. The other proportion of the innovations is sourced from the variations in the RES accounting for about $0.58 \%$ at the beginning of the period and rising to $13.38 \%$ at the end of the time horizon. Variations in the shocks of XPORT, OPN and VOL ranged between $0.07 \%-1.29 \%, 0 \%-33.97 \% \%$ and $0 \%-1.79 \%$ respectively during the ten-year horizon. Thus, the predominant variation in INTR is by its "own shock" and moderate variations in RES and OPN, but with only tiny variations in XPORT and VOL.
The forecast error variance decomposition in OPN is attributable largely to the contribution of "own shock" of about $93.5 \%$ at the start of the period which marginally decreases to $81.86 \%$ at the end of the ten-year horizon. However, only a small proportion of the innovations in OPN is sourced from the variations in RES, XPORT, INTR and VOL. The result indicates that the contribution of RES is marginal, rising from $2.86 \%$ at the beginning of the period to $7.63 \%$ at the end of the period, while the contribution of innovations in XPORT ranged from $0.32 \%$ in the first period to only $1.04 \%$ in the tenth period. The contribution of VOL ranged from $0 \%$ to $2.58 \%$ at the end of the period, while the variation of the shock in INTR ranged between $3.3 \%$ at the start of the horizon and $6.87 \%$ at the end of the horizon. Thus, the results show that the predominant variations in the OPN is accounted for by its "own shock" and only marginally by variations in the shocks of the other variables.

Finally the forecast error variance decomposition of VOL is substantially explained by its own innovations which accounted for about $70 \%$ in period 1 but declined to $50.73 \%$ in period 10 . While variations in RES contributed only $0.25 \%$ in the first period, it increased to $15.88 \%$ at the end of the tenyear period. Also the contributions of XPORT, INTR, and OPN ranged between $2.2 \%-7.88 \%, 6.74 \%-4.46 \%$ and $20.93 \%-21.03 \%$ respectively within the planning horizon. Thus, the predominant variations in VOL is accounted for by variations in its "own shock", moderately by variations in the shocks of RES and OPN, and marginally by the shocks in the other 2 variables, viz. XPORT and INTR.

Var Granger Causality Test

Table 7: VAR GRANGER CAUSALITY/BLOCK EXOGENEITY WALD TESTS

Sample: 19812017

Included observations: 35

Dependent variable: RES

\begin{tabular}{cccc}
\hline \hline Excluded & Chi-sq & Df & Prob. \\
\hline \hline XPORT & 8.114928 & 2 & 0.0173 \\
INTR & 1.141578 & 2 & 0.5651 \\
OPN & 1.088586 & 2 & 0.5803
\end{tabular}




\begin{tabular}{cccc} 
VOL & 4.578292 & 2 & 0.1014 \\
\hline \hline All & 14.03874 & 8 & 0.0808 \\
\hline \hline
\end{tabular}

Dependent variable: XPORT

\begin{tabular}{cccc}
\hline \hline Excluded & Chi-sq & df & Prob. \\
\hline \hline RES & 10.74376 & 2 & 0.0046 \\
INTR & 0.800664 & 2 & 0.6701 \\
OPN & 1.378799 & 2 & 0.5019 \\
VOL & 15.10133 & 2 & 0.0005 \\
\hline \hline All & 27.76065 & 8 & 0.0005 \\
\hline \hline
\end{tabular}

Dependent variable: INTR

\begin{tabular}{cccc}
\hline \hline Excluded & Chi-sq & df & Prob. \\
\hline \hline RES & 0.504026 & 2 & 0.7772 \\
XPORT & 1.409192 & 2 & 0.4943 \\
OPN & 7.248816 & 2 & 0.0267 \\
VOL & 0.547843 & 2 & 0.7604 \\
\hline \hline All & 8.633046 & 8 & 0.3742 \\
\hline \hline
\end{tabular}

Dependent variable: OPN

\begin{tabular}{cccc}
\hline \hline Excluded & Chi-sq & df & Prob. \\
\hline \hline RES & 0.162725 & 2 & 0.9219 \\
XPORT & 0.004199 & 2 & 0.9979 \\
INTR & 1.727029 & 2 & 0.4217 \\
VOL & 1.427426 & 2 & 0.4898 \\
\hline \hline All & 4.409257 & 8 & 0.8184 \\
\hline \hline
\end{tabular}

Dependent variable: VOL

\begin{tabular}{cccl}
\hline \hline Excluded & Chi-sq & df & Prob. \\
\hline \hline RES & 7.922100 & 2 & 0.0190 \\
XPORT & 32.02455 & 2 & 0.0000 \\
INTR & 3.932136 & 2 & 0.1400 \\
OPN & 2.178989 & 2 & 0.3364 \\
\hline \hline All & 55.91542 & 8 & 0.0000 \\
\hline \hline
\end{tabular}

Source: Authors' computation using E-views 9.0.

It is easily confirmed from Table 7 that bivariate Granger Causality exists only between RES and XPORT, and between XPORT and VOL. Thus, an important conclusion is that while international reserves Granger Causes exports, exports also Granger Causes international reserves. Hence, the most important determinant of demand for international reserves in Nigeria is export receipts. 


\section{CONCLUSION}

This paper has used the tool of vector auto-regressions to take a fresh look at the issue of obtaining the determinants of the demand for international reserves in Nigeria. It was established that in an international monetary system whose defining characteristic is "managed" exchange rates, the amount of owned international reserve assets held by a country matters a great deal. The econometric results showed that the most important exogenous variables which determine the amount of international reserves held by the central bank are exports and openness. A reciprocal Granger Causality was found to exist between international reserves and exports. Hence, arguably, exports are the most important determinant of the demand for international reserves in Nigeria. This corroborates previous results obtained by Iyoha (1976), Aizenman \& Lee (2005), Bankole et al (2011), and Osigwe, Okechukwu \& Onoja (2015). We therefore recommend that the Nigerian government should implement trade and exchange rate policies that will lead to rising export receipts in the years ahead.

\section{REFERENCES}

[1]. Abdullateef, U. and I. Waheed (2010). External reserve holdings in Nigeria: implications for investment, inflation and exchange rate. Journal of Economics and International Finance Vol.2 No. 9 pp183-189.

[2]. Aizenman, J., \& Lee, J. (2005). International reserves: precautionary vs. mercantilist views, theory and evidence. IMF Working Paper Working Paper /05/198.

[3]. Akamobi, G.O \& Ugwunna, T.O. (2017). Determinants of Foreign Reserve in Nigeria. Journal of Economics and Sustainable Development, Vol. 8(20)

[4]. Akinwunmi, A.A \& Adekoya, R. B. (2016) Reserves Management and its Effect on Economic Growth of Nigeria. International Journal of Business \& Finance Management Research IJBFMR: 4, 36-46

[5]. Akpansung, A. (2013). A Review of Empirical Literature on Balance of Payments as a Monetary Phenomenon. Journal of Emerging Trends in Economics and Management Sciences (JETEMS), 4(2), pp. 124-132.

[6]. Bankole, A. S, et al (2011), Demand For International Reserves: A Case For Reserves Accumulation In Nigeria, Central Bank of Nigeria Economic and Financial Review Volume 49/3.

[7]. Chinedu, N.G., \& Edet, A.S. (2019). Macroeconomic Implications of External Reserves Management in Nigeria: 1986-2016. IOSR Journal of Humanities and Social Science (IOSR-JHSS) Volume 24, Issue 10, 41-54

[8]. Clark, P. B. (1970). The Demand for International Reserves: A Cross-Country Analysis. Canadian Journal of Economics, vol. 3 (November), pp. 577-594.

[9]. Cooper, R. N. (1968). "The Relevance of International Liquidity to Developed Countries". American Economic Review vol. 58 (May) pp. 625-636.

[10]. Edwards, S., (1985). On the interest rate elasticity of the demand for international reserves: some evidence from developing countries, Journal of International Money and Finance, 4: 287295.

[11]. Ekpo, A. H. \& Omoruyi, S. (2011). Formulation and Implementation of Strategies for Effective Management of External Reserves: Country Experience. West African Financial and Economic Review, vol. 8, no. 2 (December), pp 1-26.

[12]. Engle, R.F. and C.W.J. Granger. 1987. Cointegration and errorcorrection: representation, estimation, and testing. Econometrica, 55:251-276.1
[13]. Gonzalo, J. 1994. Five alternative methods of estimating long run equilibrium relationships. Journal of Econometrics, 60:203-233.

[14]. Heller, H. R. and M. S. Khan (1978). The Demand for International Reserves under Fixed and Floating Exchange Rates. IMF Staff Papers, vol. 25, no. 4 (December), pp. 623-649.

[15]. International Monetary Fund (1974). Annual Report of the Executive Directors for the Fiscal Year Ended April 30, 1974. Washington, D. C.

[16]. Irefin, D., \& Yaaba, B., (2012). Determinants of foreign reserves in Nigeria: an autoregressive distributed lag approach, $C B N$ Journal of Applied Statistics, 2(2): 69.

[17]. Iyoha, M. A. (1976). Demand for International Reserves in Less Developed Countries: A Distributed Lag Specification. The Review of Economics and Statistics. vol. 58, no. 3 (August) pp. 351-355.

[18]. Iyoha, M. A. (1973). "The Optimal Balance-of-Payments Strategy of a Less Developed Country”. Economic Record vol. 49 (June), pp. 270-279.

[19]. Kalu, E.B, Ugwu, O.E, Ndubuaku, V.C, \& Ifeanyi, O.P, (2019). Exchange Rate and Foreign Reserves Interface: Empirical Evidence From Nigeria. The Economics and Finance Letters Vol. 6, No. 1, pp. 1-8 Retrived from: DOI: 10.18488/journal.29.2019.61.1.8

[20]. Kenen, P. B. and E. B. Yudin. (1965), The Demand for International Reserves. The Review of Economics and Statistics, vol. 47, no. 3 (August), pp. 242-250.

[21]. Mbeng-Mezui C. A., \& Duru, U. (2013). Holding excess foreign reserves versus infrastructure finance: what should Africa do? African Development Bank Group Working Paper series No. 178.

[22]. Nwafor, M.C. (2017). External Reserves: Panacea for Economic Growth in Nigeria European Journal of Business and Management Vol.9, No.33.

[23]. Nwakanma C \& Mgbataogu, I. (2014), Determinants of Excess Liquidity: The Nigerian Experience. International Business Research; Vol. 7, No. URL:http://dx.doi.org/10.5539/ibr.v7n6p17

[24]. Ojiako, I. A. (2020). Linkages between External Reserves and Economic Performance in Nigeria, 1981-2018: Bounds Test and ARDL Approaches. South Asian Journal of Social Studies and Economics, 6(1), 44-62. https://doi.org/10.9734/sajsse/2020/v6i130160

[25]. Olomola, P. \& Ajayi, I. (2018). The determinants of international reserves in West African States. Global Journal of Human-Social Science, 18(4), 1-9.

[26]. Osigwe, A. C., Okechukwu, A. I., \& Onoja, T. C. (2015). Modelling the determinants of foreign reserves in Nigeria. Developing Country Studies, 5 (19), 72-77.

[27]. Oyeniran, I. W. \& Alamu, S. A. (2020). Determination of Optimal Level of Foreign Reserves in Nigeria. CBN Journal of Applied Statistics, vol. 11, no. 1 (June), pp. 65-85.

[28]. Phillips, P.C.B. 1991. "Optimal inference in cointegrated systems." Econometrica, 59:283-306.

[29]. Samuel, A.O., Omotayo, E., \& Olusegun, E.A. (2019). The Relationship between External Reserve and Trade: Evidence from Nigeria. IOSR Journal of Economics and Finance (IOSRJEF).Volume 10, Issue 5, 21-27

[30]. Sanusi, K. A., Meyer, D. F. \& Hassan, A. S. (2019). An investigation of the determinants of foreign exchange reserves in Southern African Countries. Journal of International Studies, 12(2), 201-212.

[31]. Shaibu, I. \& Izedonmi, F. I. O. (2020). An Autoregressive Distributed-Lag Modeling Approach to Nigeria's External Reserves Dynamics. International Journal of Academic Research in Business and Social Sciences, 10(2), 539-557.

[32]. Sehgal, S. \& C. Sharma (2008). A Study of Adequacy, Cost and Determinants of International Reserves in India. International Research Journal of Finance and Economics Issue 20. Retrieved Mar. 20, 2008, from http://www.eurojournals.com/finance.htm.

[33]. Sims, Christopher.A. (1986). — Are Forecasting Models Usable for Policy Analysis?\| Federal Reserve Bank of Minneapolis Quarterly Review, vol. 10 (Winter 1986): 2-16. 
International Journal of Research and Innovation in Social Science (IJRISS) |Volume V, Issue II, February 2021|ISSN 2454-6186

[34]. Tule M. K., Egbuna, E.N., Sagbamah, J.E.L., Abdusalam, S.A, Ogundele, O.S,. Oduyemi A.O, \& Oladunni, S.(2015). Determination of optimal foreign exchange reserves in Nigeria.
Central Bank of Nigeria Working Paper Series CBN/WPS/01/2015/06

[35]. Williamson, J. H. (1973). "International Liquidity: A Survey". Economic Journal vol. 83 (September), pp. 685-746. 